\title{
Differential Effects of Combined N Sources on Early Steps of the Nod Factor-Dependent Transduction Pathway in Lotus japonicus
}

\author{
Ani Barbulova, Alessandra Rogato, Enrica D’Apuzzo, Selim Omrane, and Maurizio Chiurazzi \\ Institute of Genetics and Biophysics A, Buzzati Traverso, Via P. Castellino 111, 80131, Napoli, Italy \\ Submitted 12 February 2007. Accepted 2 April 2007.
}

\begin{abstract}
The development of nitrogen-fixing nodules in legumes is induced by perception of lipochitin-oligosaccharide signals secreted by a bacterial symbiont. Nitrogen $(N)$ starvation is a prerequisite for the formation, development, and function of root nodules, and high levels of combined $\mathbf{N}$ in the form of nitrate or ammonium can completely abolish nodule formation. We distinguished between nitrate and ammonium inhibitory effects by identifying when and where these combined $\mathbf{N}$ sources interfere with the Nod-factor-induced pathway. Furthermore, we present a small-scale analysis of the expression profile, under different $N$ conditions, of recently identified genes involved in the Nod-factor-induced pathway. In the presence of high levels of nitrate or ammonium, the NIN gene fails to be induced $24 \mathrm{~h}$ after the addition of Nod factor compared with plants grown under $\mathrm{N}$-free conditions. This induction is restored in the hypernodulating nitrate-tolerant har1-3 mutant only in the presence of 10 and $20 \mathrm{mM} \mathrm{KNO}$. These results were confirmed in Lotus plants inoculated with Mesorhizobium loti. NIN plays a key role in the nodule organogenesis program and its downregulation may represent a crucial event in the nitrate-dependent pathway leading to the inhibition of nodule organogenesis.
\end{abstract}

The establishment of the symbiosis program leading to the formation of nitrogen-fixing nodules begins with the mutual recognition of two partners, rhizobial bacteria and leguminous plants, which requires an exchange of molecular signals. In particular, bacterial Nod factors are produced in response to flavonoids secreted from legume roots. When purified Nod factors are added to the roots of legume seedlings, several early events take place. $\mathrm{A} \mathrm{Ca}^{2+}$ influx and a transient plasma membrane depolarization associated with $\mathrm{Cl}^{-}$and $\mathrm{K}^{+}$effluxes is detected within seconds of the addition of Nod factors (Cardenas et al. 1999; Ehrhardt et al. 1992; Felle et al. 1999). This is accompanied by the alkalinization of root hair cytoplasm (Felle et al. 1996) and, after a few minutes, by $\mathrm{Ca}^{2+}$ oscillations (Ehrhardt et al. 1996; Walker et al. 2000). Subsequently, actin filaments undergo rearrangement (Timmers et al. 1999) and root hair tip growth is redirected (Heidstra et al. 1994). Finally, a battery of genes directly involved in the morphogenetic nodulation program is induced. The recent adoption of Lotus

Corresponding author: Maurizio Chiurazzi; E-mail: chiurazz@igb.cnr.it

Current address of Ani Barbulova: Arterra Bioscience srl, Via Comunale Margherita 482, 80145, Napoli, Italy.

* The $\boldsymbol{e}$-Xtra logo stands for "electronic extra" and indicates that Figures 3 and 4 appear in color online. japonicus and Medicago truncatula as models for legume research has greatly accelerated the genetic mapping and isolation of genes involved in the Nod-factor-dependent transduction pathway. Recently discovered signaling components in the two model species include potential components of Nod factor receptors (Limpens et al. 2003; Madsen et al. 2003; Radutoiu et al. 2003); a leucine-rich repeat receptor-like kinase (Endre et al. 2002; Stracke et al. 2002); a pair of putative plastid cation channels and a nucleoporin, suggestive of the involvement of two different subcellular compartments in a calcium spiking event (Ané et al. 2004; Imaizumi-Anraku et al. 2005; Kanamori et al. 2006); a calcium/calmodulin-dependent protein kinase (CCaMK) (Levy et al. 2004; Mitra et al. 2004) which may decode the calcium oscillation signal (Gleason et al. 2006; Tirichine et al. 2006a;); a cytokinin receptor (GonzalezRizzo et al. 2006; Murray et al. 2007; Tirichine et al. 2007); a putative transcriptional activator (NIN) involved in formation of the infection thread and of nodule primordium (Schauser et al. 1999); and a pair of putative primary transcription factors of the GRAS family (Kalò et al. 2005; Smit et al. 2005).

The competence of leguminous plants for nodule formation is determined by physiological conditions. Limitation of combined $\mathrm{N}$ in the soil and active photosynthesis for an adequate supply of energy are prerequisite for symbiotic interactions. Under these conditions, a few cells in the emerging root hair zone behind the root apical meristem acquire transient competence for entering the nodule developmental program. In certain genotypes of $M$. sativa, nitrogen starvation alone is sufficient to induce the development of empty (bacterium-free) nodules (Truchet et al. 1989). Nitrogen starvation also is crucial for nodule development in spontaneous nodulation mutants recently isolated in Lotus spp. (Tirichine et al. 2006b). Small supplements of combined $\mathrm{N}$, such as $\mathrm{NO}_{3}{ }^{-}, \mathrm{NH}_{4}{ }^{+}$, and urea, added at sowing may benefit symbiosis by increasing seedling growth rate and the number, size, and efficiency of the resulting nodules, whereas the addition of excessive amounts of combined $\mathrm{N}$ depresses nodulation (Patriarca et al. 2002). However, little is known about how combined $\mathrm{N}$ sources interfere with the symbiotic program. Several observations have been reported, especially on the effect of nitrate as an inhibitor of all phases of nodulation, including bacterial infection (by reducing the number of infective sites or the number of successful infections on primary roots), nodule development, and nitrogenase function (Bisseling et al. 1978; Caetano-Anollés and Gresshoff 1991; Carroll and Mathews 1990). Hypernodulating mutants that develop surplus nodules by escaping autoregulation or that are not subject to nitrate suppression have been isolated and characterized (Krussell et al. 2002; Nishimura et al. 2002; Wopereis et al. 2000). Nitrate exerts a suppressive effect mainly 
locally, and ethylene has been postulated to be involved in nitrate repression in alfalfa but not other legumes (Penmetsa and Cook 1997). An effect of localized NO3- application on root isoflavonoid concentration has been reported for Glycine max (Cho and Harper 1991). Ammonium also is known to potently inhibit nodule formation, an effect exerted soon after inoculation, by inhibiting both initial cortical cell division and infection thread formation (Carroll and Mathews 1990; Malik et al. 1987). However, the results of these experiments are biased by an ammonium effect on the flavonoid-mediated induction of the bacterial nod genes transcription and on the production of exopolysaccharides, which play a critical role in root invasion (Patriarca et al. 2002). NH4NO3 also was reported to be an effective inhibitor of root hair deformation in Vicia sativa (Heidstra et al. 1994, 1997). Root hairs that develop in the presence of NH4NO3 do not undergo deformation when treated with Nod factors (Heidstra et al. 1994). However, because the expression of the very early Nod-factor-induced gene VsLB1 is not affected

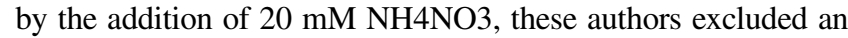
effect of NH4NO3 on Nod factor perception and transduction leading to gene expression in vetch plants (Heidstra et al. 1997).

In this article, we have thoroughly analyzed several steps of the Nod factor-induced transduction pathway in L. japonicus in the presence of different combined $\mathrm{N}$ sources. We show a direct relationship between the presence of high concentrations of combined $\mathrm{N}$ sources in the medium and the inhibition of cortical cell divisions induced by treatment with Nod factors. Furthermore, we distinguish between the effects of nitrate and ammonium on early root hair deformation. In the case of high potassium nitrate $\left(\mathrm{KNO}_{3}\right)$ concentration, we have narrowed the window of temporal events where the suppressive effect takes place and have identified downregulation of the NIN gene as one key event in this inhibitory pathway.

\section{RESULTS}

Effect of high nitrate and ammonium levels on plant growth and nodule formation in wild-type plants and hypernodulating mutants.

To characterize the effects of different combined $\mathrm{N}$ sources on the symbiotic program, we first analyzed the growth and biomass phenotypes of Lotus plants cultivated in the presence of different concentrations of ammonium and nitrate. Wildtype plants were germinated and grown on solid sterile medium containing $\mathrm{KNO}_{3}$, ammonium phosphate (AP), or ammonium succinate (AS) as sole $\mathrm{N}$ source at concentrations ranging from 0.5 to $20 \mathrm{mM}$. The two growth parameters analyzed were primary root length and fresh shoot weight (Fig. 1A and B). There were no significant changes in primary root length in 5-week-old plants growing in $\mathrm{N}$-free conditions when com- pared with plants grown on increasing concentrations of $\mathrm{KNO}_{3}$ (up to $20 \mathrm{mM}$ ) or AS $(0.5,1$, and $3 \mathrm{mM}$ ) (Fig. 1A). Instead, a slight decrease in root length was observed in the presence of 5 and $10 \mathrm{mM} \mathrm{AS}$. On the other hand, root growth was strongly inhibited even at the lowest AP concentration of $0.5 \mathrm{mM}$ (Fig. 1A). A clear deficiency also was observed for shoot biomass of plants grown on AP (Fig. 1B). In general, plants growing on AP showed severe stress symptoms with stunted shoots and roots. As expected, increased concentration of $\mathrm{KNO}_{3}$ up to 10 $\mathrm{mM}$ led to an increase in shoot biomass whereas, at $20 \mathrm{mM}$ $\mathrm{KNO}_{3}$, fresh shoot weight was reduced, with leaves showing slight stress symptoms. The same behavior was observed in plants growing on AS with no apparent stress symptoms, even at $10 \mathrm{mM}$ AS. Clorotic symptoms related to $\mathrm{N}$ starvation were observed, after 5 weeks, only in plants grown on $\mathrm{N}$-free medium or on $0.5 \mathrm{mM}$ AS (data not shown). Similar growth profiles were observed in Lotus plants grown in hydroponic conditions where the $\mathrm{pH}$ of the buffered medium could be monitored daily (data not shown).

On the basis of the analysis reported in Figure 1A and B, the effects of different concentrations of AS on the nodulation program were tested for comparison with the well-known inhibitory effect of nitrate. Lotus plants were germinated and grown in the in vitro experimental conditions described by Barbulova and Chiurazzi (2005) in the presence of varying concentrations of AS and nitrate and the effects on nodule formation in both wild-type plants and in the hypernodulating harl-3 mutant (Krusell et al. 2002) were examined 5 weeks after inoculation. As expected, the addition of $1 \mathrm{mM}$ nitrate enhanced nodule formation when compared with growth medium without a $\mathrm{N}$ source, and nodule number decreased gradually when nitrate concentration was increased up to $10 \mathrm{mM}$ (Fig. 2A and B) (Hussain et al. 1999). It is noteworthy that some nodules still formed at this high concentration. The harl-3 plants showed a clear tolerance to nitrate compared with wild-type plants at high nitrate concentrations, but they behaved similarly to wildtype plants with a gradually reduced number of nodules at higher nitrate concentrations (Fig. 2A and B). The presence of $0.5 \mathrm{mM}$ AS caused a slight increase in the number of nodules per plant when compared with plants grown under $\mathrm{N}$-free conditions whereas, at $1 \mathrm{mM}$ AS, this number did not change significantly when compared with control plants (Fig. 2A and B). The harl-3 plants showed a hypernodulation phenotype at both 0.5 and $1 \mathrm{mM}$ AS, although the number of nodules was lower than in control plants grown in the presence of nitrate (Fig. 2A and B). In contrast, $2 \mathrm{mM}$ AS appeared to be inhibitory for the symbiosis in both wild-type and harl;3 plants. The harl-3 symbiotic phenotypes observed in the presence of AS included an increased shoot biomass, with a fresh shoot weight comparable with that of wild-type plants (data not shown).
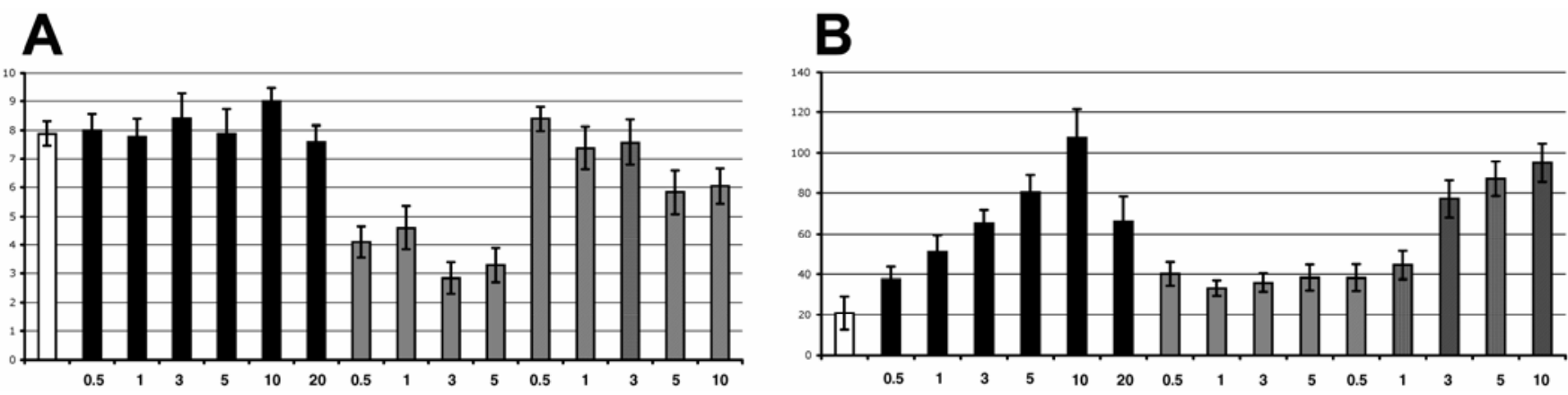

Fig. 1. Analysis of growth and biomass phenotypes in Lotus plants grown for 5 weeks in the presence of different combined $\mathrm{N}$ sources. A, Length of the primary root. B, Weight of fresh shoots. Numbers indicate the concentration in $\mathrm{mM}$ of the different $\mathrm{N}$ sources utilized. White bar $=\mathrm{N}$-free, black bars $=$ $\mathrm{KNO}_{3}$, gray bars = ammonium phosphate, and filled bars $=$ ammonium succinate. 
In our experimental conditions, an analysis of the nodulation phenotype in the presence of higher concentrations of AS could not be performed because of bacterial overgrowth due to the use of succinate as a carbon source, which strongly affected plant growth. A counterselection with antibiotics could not be exploited because of its effect on the Rhizobium spp. invasion capacity even if applied a few days after inoculation (data not shown).

\section{Nod-factor-induced mitogenic response in the presence of different $\mathbf{N}$ sources.}

To avoid the side effects due to succinate-dependent bacterial overgrowth and to completely uncouple the possible effects of combined $\mathrm{N}$ on bacterial Nod factor synthesis or invasion capacities (Patriarca et al. 2002), we decided to test the effects of $\mathrm{KNO}_{3}$ and $\mathrm{AS}$ on nodule organogenesis triggered by the addition of purified Nod factors. $\mathrm{NH}_{4} \mathrm{NO}_{3}$ also was used for comparison, as inspired by previous data concerning the effects of this combined $\mathrm{N}$ source on Nod-factor-induced responses in $V$. sativa (Heidstra et al. 1994, 1997). We first compared the root phenotype of Lotus plants with a 2-cm-long primary root grown for 6 days on solid medium either without $\mathrm{N}$ or with 10 $\mathrm{mM} \mathrm{KNO}{ }_{3}$ or $\mathrm{AS}$ a nitrogen source. Root cellular organization was assessed by microscopic examination of longitudinal and cross sections. Young primary roots sectioned in the Nod-factorresponsive region (approximately $0.5 \mathrm{~cm}$ from the root tip) displayed a single outer layer of epidermal cells, three to four elongated cortical cell layers surrounding a single layer of endodermal cells, and an innermost region consisting of a single layer of pericycle cells enclosing the vascular cylinder (Fig. $3 \mathrm{~A})$. This organization was observed in $\mathrm{N}$-free conditions as well as in the presence of $10 \mathrm{mM} \mathrm{NH}_{4} \mathrm{NO}_{3}, \mathrm{KNO}_{3}$ (Fig. 3A), or AS (data not shown), with no apparent differences in the number and size of root cells. We then tested the effect of Nod factor addition on the induction of cortical cell division in $\mathrm{Lo}$ tus roots, a phenomenon that has been well described by van Spronsen and associates (2001). Six-day-old seedlings with straight roots $(1.5 \mathrm{~cm}$ in length) were selected and Nod factors at a $10^{-9} \mathrm{M}$ concentration were mixed with $1 \%$ low-melt agarose prewarmed at $55^{\circ} \mathrm{C}$ and spot inoculated onto the competent region of primary roots. Five days after the addition of purified Nod factors, roots of seedlings grown without a $\mathrm{N}$ source showed activated and mitogenic activity zones in the region of inoculation (Fig. 3B). Serial longitudinal sections of the application area showed activated cortical cells containing large nuclei with distinct prominent nucleoli, and cytoplasmic bridges with a swollen nucleus were observed mainly in the second cortical cell layers (Fig. 3B). Cell divisions, primarily in an anticlinal direction were observed in the second and third cortical cell layers. In some cases, it was possible to observe the development of cortical root hairs between two epidermal cells (van Spronsen et al. 2001; data not shown). Activation zones and mitogenic activity were not seen in longitudinal root sections of control plants that were not treated with Nod factor or in plants grown in the presence of $10 \mathrm{mM} \mathrm{NH} \mathrm{NO}_{3}, \mathrm{KNO}_{3}$ (Fig. 3B), or AS (data not shown) 5 days after addition of lipochitin-oligosaccharides (LCOs), thus demonstrating a direct effect of these combined $\mathrm{N}$ sources on the cortical cell division event induced by Nod factors.

\section{Effects of different $\mathbf{N}$ sources on root hair deformation.}

To test the possible effect of high concentrations of combined $\mathrm{N}$ sources on earlier steps of the Nod-factor-dependent pathway, we analyzed the induction of root hair deformation. Lotus plants were grown as described below. Before the addition of Nod factors, the root hairs were examined microscopically and plants with deformed root hairs were discarded. The developmental program and growth of root hairs appeared identical in young seedlings germinated in the presence of different ammonium and nitrate sources (data not shown). At $24 \mathrm{~h}$ after Nod factor addition, the susceptible zone of primary roots was examined for root hair deformation (Heidstra et al. 1994). The most prominent phenotype was an early reinitiation of root hair tip growth, but swelling and branching also were detected (Fig. 4A). These three phenotypes were analyzed to semiquantitatively characterize root hair deformation in plants grown in the presence of varying concentrations of different nitrate and ammonium sources.. As expected, root hair deformation was observed only in the susceptible narrow region ( $2 \mathrm{~mm}$ long) of roots with growing root hairs. These phenotypes were highly reproducible in independent experiments and in a range of Nod factors concentrations spanning $10^{-8}$ to $10^{-10} \mathrm{M}$. Only $9 \%$ of the root hairs of control plants untreated with Nod factors showed deformation phenotypes in the susceptible zone under our experimental conditions (Fig. 4B). When Nod factors were added to the roots of plants grown in $\mathrm{N}$-free conditions, ap-
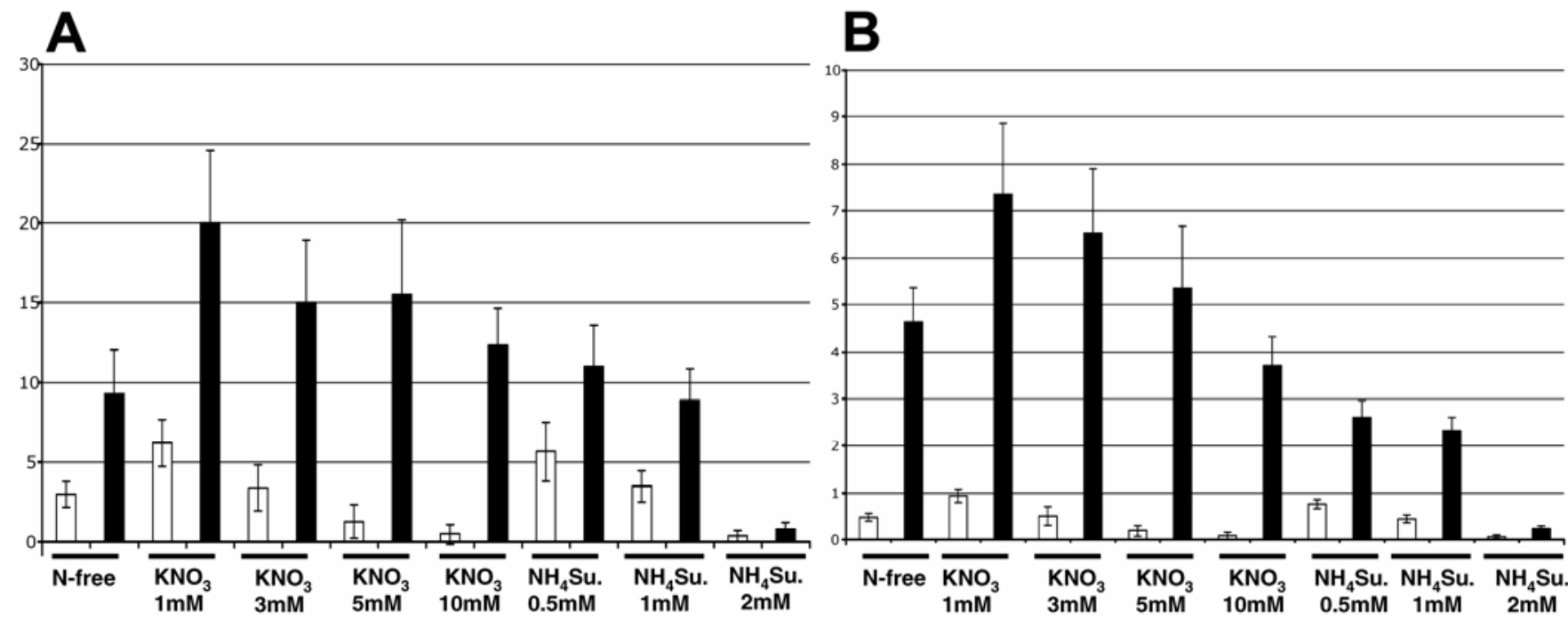

Fig. 2. Analysis of nodule formation in the presence of varying concentrations of $\mathrm{KNO}_{3}$ and ammonium succinate $\left(\mathrm{NH}_{4} \mathrm{Su}\right)$. $\mathbf{A}$, Number of mature nodules observed for individual wild-type (white bars) and harl-3 (black bars) plants 5 weeks after inoculation with Mesorhizobium loti. B, Numbers of mature nodules formed per centimeter of primary root of wild-type (white bars) and harl-3 (black bars) plants. The N regimes used in the varying conditions are indicated. 
proximately $42 \%$ of root hairs $(P<0.0001)$ showed deformation phenotypes in the competent zone (Fig. 4B). This frequency was reduced to that of the untreated control when plants were grown in the presence of $10 \mathrm{mM} \mathrm{NH}_{4} \mathrm{NO}_{3}(P=$ $0.87)$ or ammonium succinate $(P=0.395)$, whereas Lotus

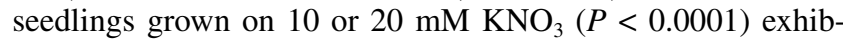
ited the Nod-factor-dependent root hair deformation response (Fig. 4B).

\section{Analysis of genes expressed early in the Nod factor transduction pathway.}

On the basis of the results described above, we concluded that high concentrations of nitrate and ammonium interfere with the cascade of events induced by the addition of purified Nod factors and that, in the case of nitrate, this effect occurs between the root hair deformation and cortical cell division steps. To determine whether this nitrate-dependent phenotype is associated with alterations in the expression of genes involved in the Nod-factor-dependent transduction pathway, we first tested expression of the NIN gene, which plays a critical role downstream of the root hair deformation event by controlling infection thread formation and cortical cell division (Schauser et al. 1999). As expected, real-time reverse-transcriptase polymerase chain reaction (RT-PCR) analysis indicated that, in 6day-old seedlings grown in $\mathrm{N}$-free conditions, there was a 20fold induction of NIN expression $24 \mathrm{~h}$ after the addition of Nod factors when compared with NIN expression in unexposed seedlings (Fig. 5). Consistent with reported results (Radutoiu et al. 2003), this level of induction was reduced to approxi- mately $50 \%$ when plants were left for 24 additional hours under permissive conditions (data not shown). When wild-type plants were grown in the presence of 10 or $20 \mathrm{mM} \mathrm{KNO}_{3}$, NIN gene induction was reduced to 27 and $14 \%$ of the level observed in $\mathrm{N}$-free conditions $(P=0.02$ and 0.003$)$, respectively (Fig. 5). In contrast, full NIN gene induction was restored in harl-3 plants grown under the same inhibitory conditions (Fig. 5). At $24 \mathrm{~h}$ after Nod factor application, we observed only slight differences between the level of NIN expression in harl3 plants grown in the presence of 10 or $20 \mathrm{mM} \mathrm{KNO}_{3}$ and in wild-type plants grown in $\mathrm{N}$-free conditions. This pattern of NIN expression in wild-type and harl-3 plants grown in $\mathrm{N}$-free conditions and in the presence of 10 and $20 \mathrm{mM} \mathrm{KNO}_{3}$ also was confirmed after Mesorhizobium loti inoculation (Fig. 6). When we analyzed the profile of NIN gene expression in wildtype plants grown in the presence of $10 \mathrm{mM} \mathrm{NH}_{4} \mathrm{NO}_{3}$, or AS, the level of induction was only approximately $10 \%(P=0.002)$ of the level observed under $\mathrm{N}$-free conditions (Fig. 5). In the harl-3 genetic background, NIN expression under the same growth conditions was maintained at the same low level with no significant changes (Fig. 5), indicating that the harl-3 mutation does not bypass the inhibitory effect of ammonium sources. To determine whether inhibition of the Nod-factordependent pathway was due to a direct effect of ammonium sources on Nod factor biological activity, Lotus plants were grown in $\mathrm{N}$-free conditions and shifted to $10 \mathrm{mM} \mathrm{NH}_{4} \mathrm{NO}_{3}$ at the time of Nod factor addition. The NIN gene still was induced $24 \mathrm{~h}$ later, although only up to $38 \%(P=0.04)$ of the level observed in permissive conditions (Fig. 5). We also tested
A

\section{$\mathrm{N}$-free}

\section{$10 \mathrm{mM} \mathrm{KNO}_{3}$}
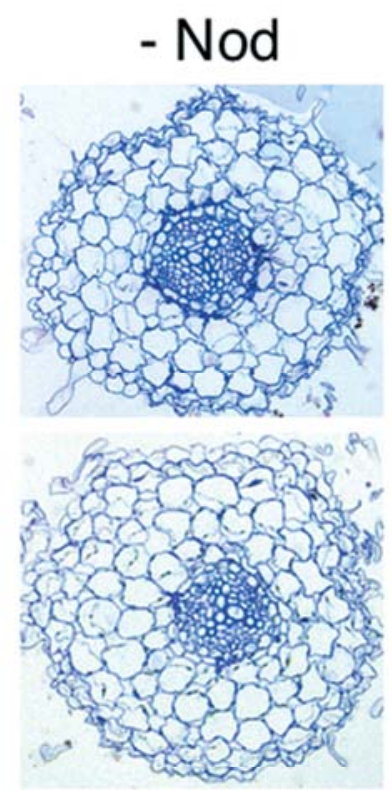

$10 \mathrm{mM} \mathrm{NH}_{4} \mathrm{NO}_{3}$

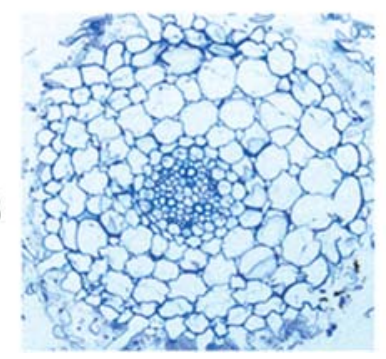

B
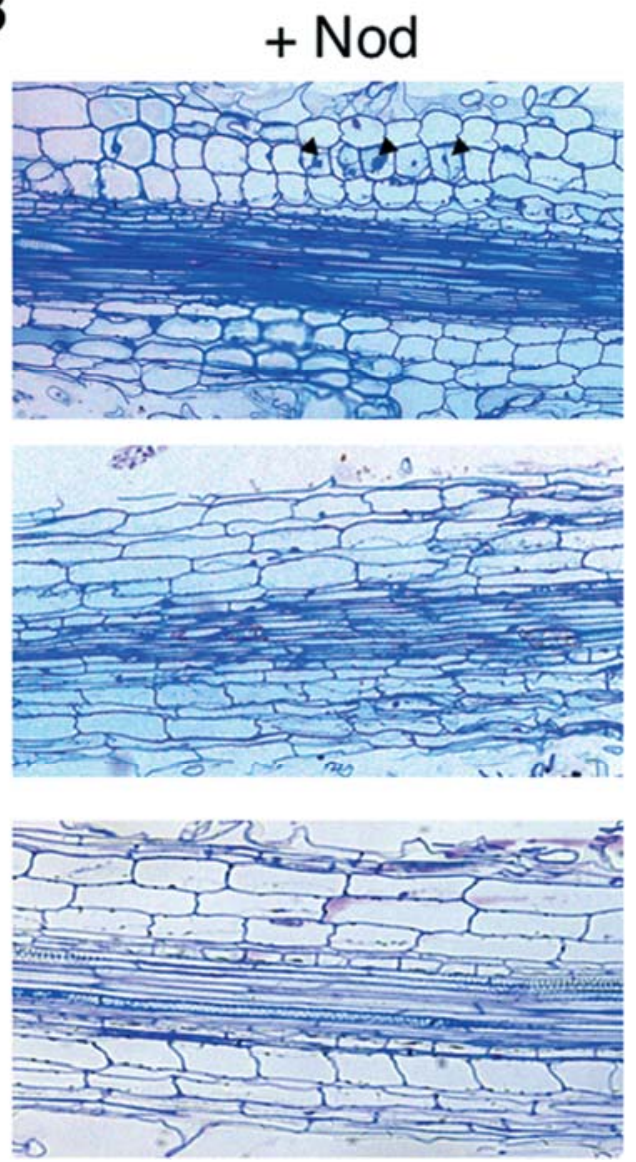

Fig. 3. Optical microscopy analysis of the cortical early response to Nod factors. A, Bright-field micrographs of semi-thin cross sections of Lotus roots of control plants spot inoculated with water agar. B, Bright-field micrographs of semi-thin longitudinal sections of Lotus roots in the Nod factor spot inoculated regions. In $\mathrm{N}$-free permissive conditions, anti-clinal cell divisions are localized in the area of the outer cortex. Cytoplasmic bridges with swollen nuclei are formed in the second cortical cell layer (arrowheads). The $\mathrm{N}$ regimes used in the varying conditions are indicated. 
whether the profile of expression of other genes acting earlier than, or concomitantly with, NIN in the cascade of events induced by Nod factors was affected by the combined $\mathrm{N}$ sources utilized for plant growth. For this purpose, we performed real-time RT-PCR to monitor expression of the NFR1, NFR5, CASTOR, POLLUX, NSP1, and NSP2 genes $24 \mathrm{~h}$ after Nod factor application (Fig. 7). NFR1, NFR5, CASTOR, and $P O L L U X$ are reported to be insignificantly affected by either Nod factor addition or $M$. loti infection (Imaizumi-Anraku et al. 2005; Madsen et al. 2003; Radutoiu et al. 2003), or to be induced at 4 and 8 days post inoculation, as in the case of NSP1 and NSP2, respectively (Heckmann et al. 2006; Murakami et al. in press). The analysis reported in Figure 7 indicates, with the exception of CASTOR, statistically significant differences in the level of expression of the tested genes in plants treated with some of the $\mathrm{N}$ sources. In particular, in the presence of 10 $\mathrm{mM}$ AS, all genes tested showed a low level of expression compared with what was observed with the other $\mathrm{N}$ sources, whereas several genes were slightly induced when the $\mathrm{N}$ source was $\mathrm{KNO}_{3}$ (NFR5, POLLUX, and NSPl in $10 \mathrm{mM}$ and $\mathrm{NSP} 2$ in $20 \mathrm{mM} \mathrm{KNO}_{3}$ ).

\section{DISCUSSION}

We have described here the effects of high concentration of different combined $\mathrm{N}$ sources on the early steps of the symbiotic program induced by Nod factor perception and transduction. The analysis reported in Figure 1 identifies AS as an informative nutrient source for investigating ammonium effects on Nod-factor-dependent nodulation. The differences shown in Figure 1 could be related to acidification of the media, although growth parameters in hydroponic cultures, in which the nutrient solution was replaced every 2 days and the $\mathrm{pH}$ was monitored daily (with slight oscillations between 5.7 and 6.0) (Tolley-Henry and Raper 1989), were similar to those in solid medium. Another possibility is that the differences between AS and AP reflect a different capacity for ammonium delivery at the experimental $\mathrm{pH}$ value.

Our data reveal that combined $\mathrm{N}$ sources (potassium nitrate, ammonium nitrate, or ammonium succinate) exert an inhibi-

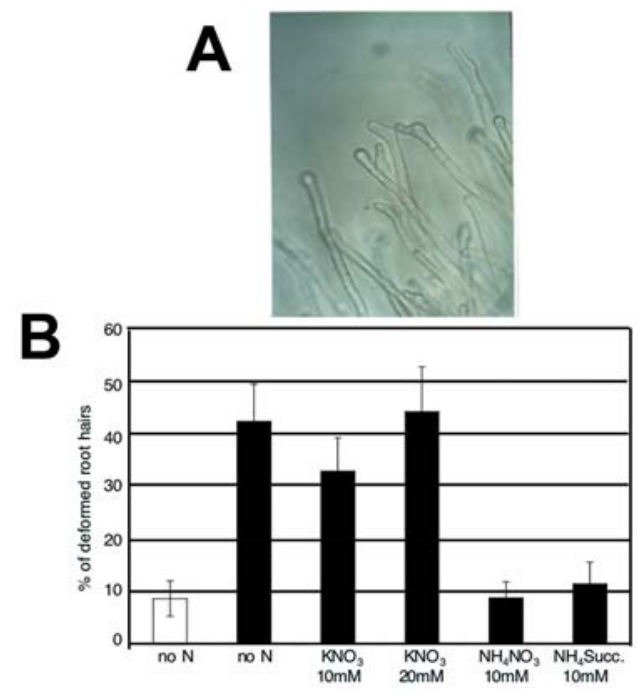

Fig. 4. Root hair deformation analysis. A, Root hair deformation of wildtype Lotus roots grown in N-free conditions $24 \mathrm{~h}$ after application of Nod factor $\left(10^{-9} \mathrm{M}\right)$. B, Frequency $(\%)$ of deformed root hairs observed in the susceptible zone after addition of Nod factors $\left(10^{-9} \mathrm{M}\right)$. White bar indicates the root control not treated with Nod factor in permissive N-free conditions. The $\mathrm{N}$ regimes used in the varying conditions are indicated. Data bars represent the mean and standard deviations of data obtained from three different experiments (eight plants per experiment). tory effect on cortical cell division (Fig. 3B). A general pleiotropic effect of high concentrations of the combined $\mathrm{N}$ sources utilized in our experimental conditions is not likely, because an analysis of plant growth and development (Fig. 1) indicates that increased levels of nitrate and ammonium succinate do not provoke a visible stress response in 5-week-old plants, except for slight symptoms in the presence of $20 \mathrm{mM}$ $\mathrm{KNO}_{3}$. Furthermore, the analysis of Nod-factor-dependent cortical cell divisions and of root hair deformation was performed on 6-day-old seedlings, in which growth and development

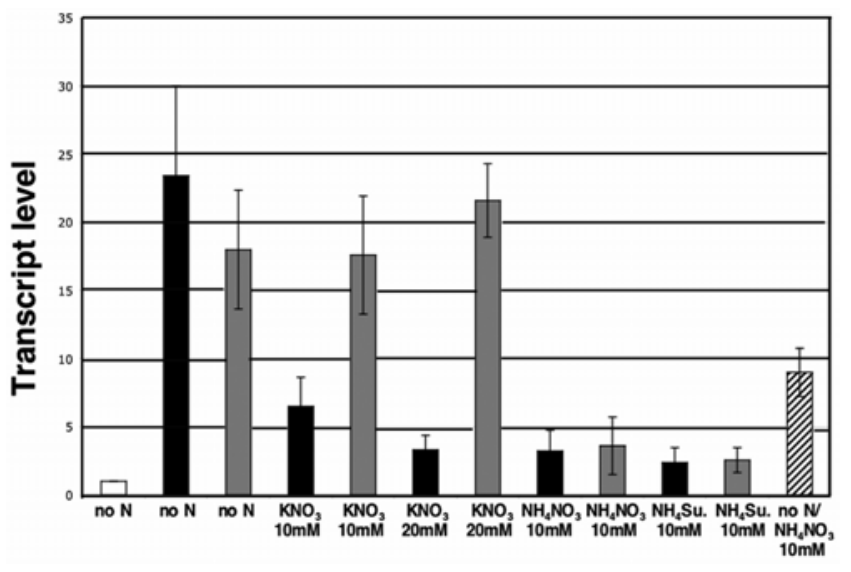

Fig. 5. Real-time reverse-transcriptase polymerase chain reaction (PCR) analysis of NIN gene expression in wild-type and harl-3 plants $24 \mathrm{~h}$ after treatment with Nod factor. Total RNA was prepared from Lotus roots $24 \mathrm{~h}$ after addition of Nod factors. NIN expression levels were normalized to that of the internal control ubiquitin and plotted relative to its expression in permissive $\mathrm{N}$-free conditions without Nod factor application (white bar). The level of NIN expression in roots $24 \mathrm{~h}$ after the addition of Nod factor is shown for wild-type plants (black bars) and harl-3 plants (gray bars) grown in the presence of different combined $\mathrm{N}$ sources as indicated. Filled bar indicates the level of NIN expression in roots of wild-type plants grown in $\mathrm{N}$-free conditions and shifted to $10 \mathrm{mM} \mathrm{NH}_{4} \mathrm{NO}_{3}$ at the time of Nod factor addition. Data bars represent the mean and standard deviations of data obtained with RNA extracted from three different sets of plants and six real-time PCR experiments.

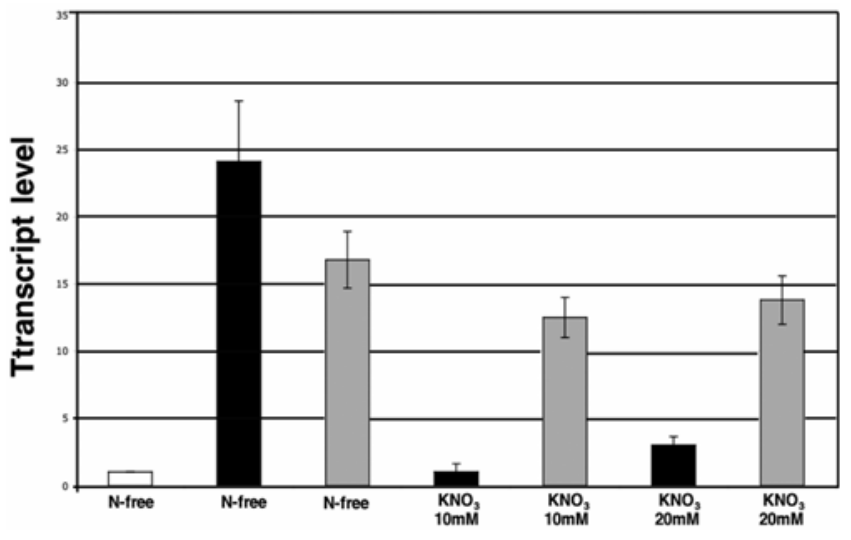

Fig. 6. Real-time reverse-transcriptase polymerase chain reaction (PCR) analysis of NIN gene expression in wild-type and harl-3 plants after Mesorhizobium loti inoculation. Total RNA was prepared from Lotus roots $24 \mathrm{~h}$ after addition of Nod factor. NIN expression levels were normalized with respect to the internal control ubiquitin and plotted relative to its expression in permissive $\mathrm{N}$-free conditions without Nod factor application (white bar). Black bars indicate the level of NIN expression $24 \mathrm{~h}$ after $M$. loti inoculation in roots of wild-type plants grown in the presence of 10 or $20 \mathrm{mM} \mathrm{KNO}$. Gray bars indicate the level of NIN expression $24 \mathrm{~h}$ after $M$. loti inoculation in roots of harl-3 plants grown in the presence of 10 or $20 \mathrm{mM} \mathrm{KNO}_{3}$. Data bars represent the mean and standard deviations of data obtained with RNA extracted from two different sets of plants and four real-time PCR experiments. 
should not depend on an external $\mathrm{N}$ supply. The inhibitory effect of combined $\mathrm{N}$ sources on cortical cell division induced by Rhizobium spp. infection has been reported several times (Patriarca et al. 2002); however, until now, it was not possible to rule out the hypothesis that this effect was directed against a pathway induced by bacterial signals released during early infection steps and different from Nod factors.

When we tested the effect of combined N sources on Nodfactor-induced root hair deformation, which takes place earlier than cell division, we did not observe a significant quantitative effect in the presence of 10 or $20 \mathrm{mM} \mathrm{KNO}_{3}$, whereas the continuous presence of $\mathrm{NH}_{4} \mathrm{NO}_{3}$ or $\mathrm{AS}$ was sufficient to inhibit this response (Fig. 4). Thus, we conclude that the inhibitory effect associated with the continuous presence of nitrate as sole $\mathrm{N}$ source occurs after root hair deformation (characterized by swelling, branching, and regrowth) in the Nod-factorinduced pathway and before cortical cell division, whereas ammonium sources apparently exert an influence before the root hair response (Fig. 8). To our knowledge, a similar analysis was performed only with $V$. sativa seedlings by Heidstra and associates $(1994,1997)$, who reported an inhibitory effect of 10 and $20 \mathrm{mM} \mathrm{NH}_{4} \mathrm{NO}_{3}$ on Nod-factor-induced root hair deformation but did not discriminate between the effects of ammonium and nitrate sources. In those studies, the inhibition of deformation was observed only in root hairs that developed in the presence of $\mathrm{NH}_{4} \mathrm{NO}_{3}$, whereas this $\mathrm{N}$ source did not block deformation of root hairs that developed in the absence of $\mathrm{NH}_{4} \mathrm{NO}_{3}$ (Heidstra et al. 1994). The effect of nitrate as sole $\mathrm{N}$ source on the root hair response previously was reported only for Rhizobium spp.-inoculated Medicago sativa plants, which indicated that it an inhibits new root hair formation and curling (Munns 1968) although, in this study, the decrease in root hair deformation could not fully account for the observed inhibition of nodule formation.

The temporal window of action of the high nitrate concentration is similar to that suggested for the NIN protein on the basis of phenotypic analysis of Lotus and pea mutants. The nin mutants present extensive root-hair deformation, with a complete absence of infection thread formation and cortical cell division, whereas arbuscular mycorrhizal association is unaffected (Borisov et al. 2003; Schauser et al. 1999). Thus, the compe- tence of root hair cells in the infection zone and their responsiveness to Nod factors is unaffected in nin mutants. Those findings place NIN downstream of Nod-factor-specific signal perception and root hair deformation and upstream of infection thread formation and cortical cell division (Fig. 8). Therefore, we analyzed the transcriptional regulation of the NIN gene in the presence of different combined $\mathrm{N}$ sources and observed a stringent alteration of its expression profile. In particular, the 20 -fold level of induction observed $24 \mathrm{~h}$ after Nod factor addition to seedlings grown in $\mathrm{N}$-free conditions was reduced to 27 and $14 \%$ when plants were plants in the presence of $10 \mathrm{mM}$ and $20 \mathrm{mM} \mathrm{KNO}_{3}$, respectively, and this effect was comparable with that observed in the presence of ammonium sources

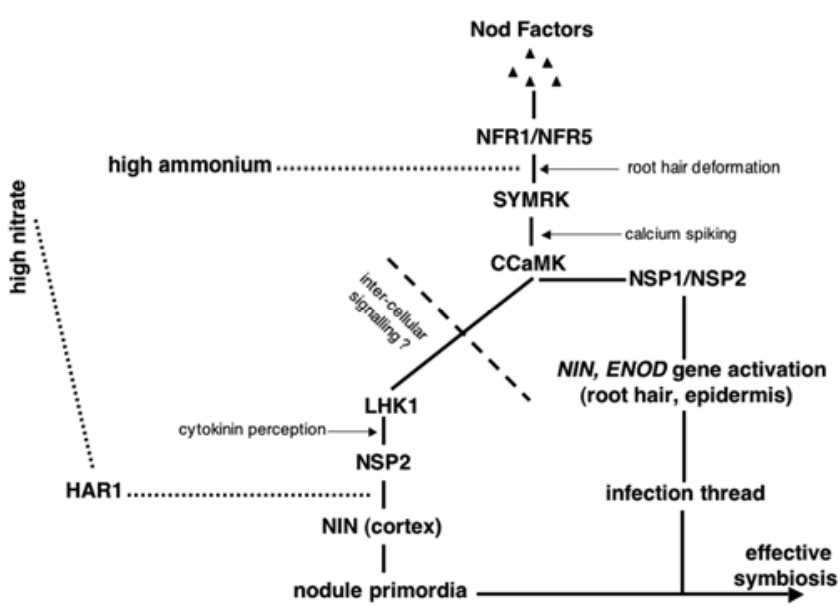

Fig. 8. Nod-factor-dependent and putative nitrate and ammonium signaling pathways in Lotus japonicus roots. Root hair deformation is represented as NFR1- and NFR5-dependent because $n f r l$ and $n f r 5$ plants are the only known mutants that lacks this response to Nod factor treatment (Miwa et al. 2006; Radutoiu et al. 2003). The dashed line indicates the putative position of the cellular signaling event as reported by Tirichine and associates (2007) and Murray and associates (2007). The square dotted lines indicate the putative nitrate-dependent and ammonium-dependent signaling pathways. We indicated a NSP2-dependent expression of NIN in cortical cells, although the experiments described in Murakami and associates (in press) cannot discriminate between epidermal and cortical NIN induction.

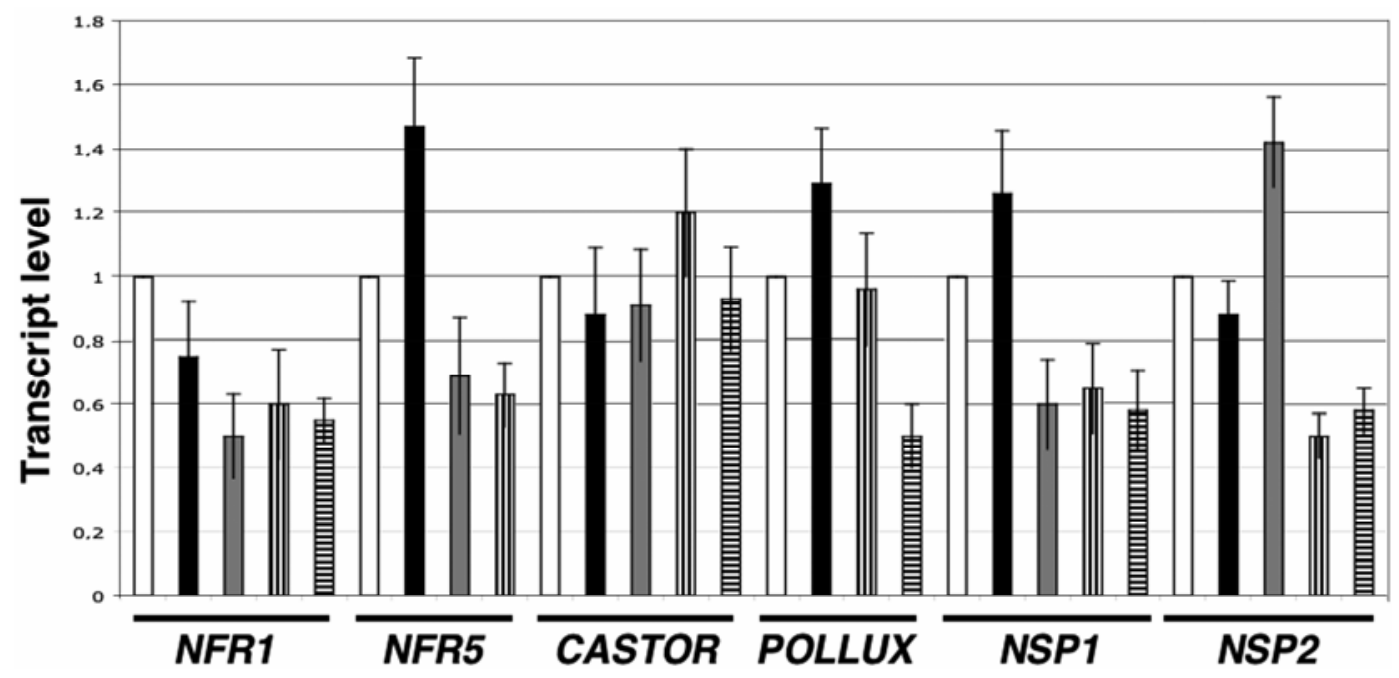

Fig. 7. Real-time reverse-transcriptase polymerase chain reaction (PCR) analysis of gene expression in wild-type plants grown in different N regimes. Total RNA was prepared from Lotus roots 24 h after the addition of Nod factors. NFR1, NFR5, CASTOR, POLLUX, NSP1, and NSP2 expression levels were normalized with respect to the internal control ubiquitin (see Material and Methods) and plotted relative to their expression in permissive $\mathrm{N}$-free conditions $24 \mathrm{~h}$ after Nod factor application. Different filled pattern of the bars identify the different $\mathrm{N}$ regime conditions: white bars $\left(\mathrm{N}\right.$-free), black bars ( $10 \mathrm{mM} \mathrm{KNO}{ }_{3}$, grey bars $\left(20 \mathrm{mM} \mathrm{KNO}_{3}\right)$, vertical filled bars $\left(10 \mathrm{mM} \mathrm{NH}_{4} \mathrm{NO}_{3}\right)$, and horizontal filled bars (10 mM ammonium succinate). Data bars represent the mean and standard deviations of data obtained with RNA extracted from three different sets of plants and six real-time PCR experiments. 
(Fig. 5). NIN homologues have been found in Lotus spp., Arabidopsis, and rice and they constitute small gene families. In particular, a class of nine NIN-like proteins sharing similarity throughout their entire length was found in Arabidopsis, and microarray analysis in response to nutrient treatment shows a nitrate-dependent inhibition pattern for at least two of them.

The mRNA steady-state levels of other genes involved in Nod factor perception (NFRl and NFR5), calcium spiking (POLLUX), gene activation, and cortical cell divisions (NSPl and NSP2) were slightly altered by the presence of $\mathrm{KNO}_{3}$, $\mathrm{NH}_{4} \mathrm{NO}_{3}$, or AS (Fig. 7). The biological relevance of these differences (maximally a twofold increase in a few cases, when compared with plants grown in $\mathrm{N}$-free permissive conditions) needs to be further investigated; however, it is unlikely that this poor level of transcriptional regulation of genes that are constitutively expressed at a significant level in uninoculated roots is crucial for the progress of the symbiotic program (Fig. 2 ), although we cannot exclude a $\mathrm{N}$-dependent effect on the activity of these gene products.

Heidstra and associates (1997) reported that a concentration of $20 \mathrm{mM} \mathrm{NH}_{4} \mathrm{NO}_{3}$ had no effect on the level of expression of the $V$. sativa leghemoglobin gene ( $V s L B 1)$, which was strongly induced $1 \mathrm{~h}$ after Nod factor application, whereas VsENOD5 and VsENOD12 expression, which normally are enhanced $3 \mathrm{~h}$ after the addition of Nod factor, were downregulated under that same condition (Heidstra et al. 1997). Thus, consistent with our data, the Nod-factor-dependent level of expression of vetch genes that are temporally regulated during the symbiotic program can be differentially affected by the presence of high levels of combined $\mathrm{N}$ sources (Figs. 5, 6, and 7).

The data shown in Figures 5 and 6 indicate that full induction of the NIN gene was restored in the harl-3 mutant grown in the presence of 10 or $20 \mathrm{mM} \mathrm{KNO}_{3} 24 \mathrm{~h}$ after Nod factor addition and Mesorhizobium loti infection, respectively, whereas we did not observe any rescue of the level of expression in the presence of ammonium sources (Fig. 5). The latter result is consistent with the inhibitory effect on nodulation exerted by 2 mM AS on both wild-type and harl-3 plants. A direct effect on the biological activity of Nod factor leading to inhibition of the Nod-factor-dependent transduction pathway cannot be excluded, because NIN expression was only partially induced $(38 \%)$ in Lotus wild-type plants grown in $\mathrm{N}$-free conditions and shifted to a medium containing $10 \mathrm{mM} \mathrm{NH} \mathrm{NO}_{3}$ at the moment of Nod factor addition (Fig. 5). Another possibility is that the observed phenotype was due to other signaling pathways dependent on ammonium sources present in the medium but not related to the nutritional status of the plants (Fig. 1). In the case of $\mathrm{KNO}_{3}$, the observed rescue of NIN expression in the harl-3 genetic background rules out the hypothesis that the inhibition observed in wild-type plants is due to a direct nitrate-dependent effect on the biological activity of Nod factor. The HARl gene encodes a serine/threonine receptor kinase that is required for shoot-controlled regulation of nodule number and for nitrate sensitivity during symbiotic development (Krusell et al. 2002). This mutant also is characterized by a pleiotropic nonsymbiotic phenotype, with an alteration of root architecture due to inhibition of root elongation, diminution of root diameter, and stimulation of secondary root initiation (Wopereis et al. 2000).

Recently, a spontaneous nodulation phenotype (i.e., in the absence of Rhizobium spp. or Nod factor) has been reported for Lotus plant lines (snf mutants) carrying mutated alleles of CCaMK and showing a residual level of constitutive substrate phosphorylation activity (Tirichine et al. 2006a,b). CCaMK probably is involved in the decoding of the calcium spiking signal induced by Nod factors. This spontaneous nodulation phenotype, independent of Nod-factor perception, provides good evidence for a pivotal role of $\mathrm{CCaMK}$ in the transduction pathway leading to nodule primordium formation, where any parallel signal transduction pathway downstream of Nod-factor perception, or other signals from rhizobia required for the initiation of cell division, must converge at or above the point of CCaMK activation (Fig. 8) (Tirichine et al. 2006a). The NSPdependent constitutive expression of the ENOD11 gene observed in Medicago truncatula plants transformed with constitutively activated CCaMK constructs (Gleason et al. 2006) places CCaMK upstream of the NSP1/NSP2 factors in the signaling cascade (Fig. 8). Furthermore, genetic analysis demonstrated that the HAR1 shoot-derived autoregulatory signal acts downstream of CCaMK in the symbiotic transduction pathway (Tirichine et al. 2006a).

It is difficult to position NIN in this plethora of factors involved in the Nod-dependent transduction pathway. The induction of the NIN gene is dependent on NFR1, NFR5, SYMRK, and NSP2 (Murakami et al. in press; Radutoiu et al. 2003) (Fig. 8), and a recent analysis of a transgenic line carrying a pNIN-gusA fusion construct allowed identification of a dual pattern of NIN expression that is temporally and spatially separated (Tirichine et al. 2006a) that could not be distinguished by our real-time RT-PCR analysis. A $\beta$-glucuronidase activity that is dependent on Nod-factor perception and not affected by snf mutations is observed first in root hairs and epidermal cells (Radutoiu et al. 2003; Tirichine et al. 2006a) and blue staining is detected only later in primordial foci and developing nodules (Tirichine et al. 2006a). NIN expression in the epidermal zone probably still depends on residual CCaMK activity in snf mutants (Tirichine et al. 2006a) and, hence, must be placed downstream of this calcium-calmodulin binding protein in the induction cascade (Fig. 8).

More recently, the downstream steps in the chain of events leading to cortical cell division and nodule primordium formation were elucidated further by the identification of a cytokinin receptor in L. japonicus (LHK1) (Murray et al. 2007; Tirichine et al. 2007) and M. truncatula (CRE1) (Gonzalez-Rizzo et al. 2006). A mutation in the Lotus LHK1 gene responsible for a spontaneous nodulation phenotype (snf2) does not confer the same phenotype in the nin and $n s p 2$ mutant genetic backgrounds (Tirichine et al. 2007), and a loss of function mutation in the same gene (hitl) inhibits the benzyl adenine (BA)-dependent accumulation of NIN transcript (Murray et al. 2007). These results indicate that cytokinin signal perception acts before cell division initiation. In addition, the hypernodulated phenotype of the snf 2 harl-1 double mutant indicates that the shoot-controlled autoregulation of root nodule number acts downstream of the cytokinin signaling perceived by the $L H K 1$ gene (Tirichine et al. 2007). However, our data indicate that NIN expression also is controlled by HAR1 because the nitrate inhibitory effect on the induction of NIN transcription is rescued in the harl-3 genetic background (Figs. 5 and 6 ). Thus, the nitrate inhibitory pathway may downregulate NIN gene expression after Nod-factor perception, calcium spiking, and root hair deformation through the action of the key regulator HAR1 (Fig. 8).

The question of whether nitrogen limitation in the legumeRhizobium spp. symbiosis simply represents a nutritional deficiency or is also a signal that is locally perceived by roots that then leads to the nodulation program is still open. However, the inhibition of nodulation by nitrate does not depend on its assimilation by nitrate reductase (Carroll and Mathews 1990), and experiments using split root systems indicate that nitrate acts locally and, hence, that its influence likely is not due to a nutritional effect. A proposed model (Caetano-Anolles and Gresshoff 1991) postulates that localized nitrate acts by determining a decrease in isoflavonoid levels (Cho and Harper 1991) that normally are induced by Nod factors (Schmidt et al. 1994) and that act as auxin-transport inhibitors (Jacobs and 
Rubery 1988). Recently, a nitrate transporter was reported to have a role as a sensor or signal transducer to coordinate the development of the Arabidopsis thaliana root system and, in particular, the initiation of secondary root formation (a process sharing many features with nodule formation), in response to nutritional cues (Little et al. 2005; Remans et al. 2006).

In summary, our results indicate differential modes of action for the ammonium and the nitrate-dependent inhibition of the symbiotic program leading to the formation of nitrogen-fixing nodules (Fig. 8). In the case of the nitrate effect, our analysis identifies downregulation of the NIN gene as a crucial event of this inhibitory pathway. Further studies based on analysis of transgenic plants harboring constructs in which NIN expression is driven from different root-specific or nodule-specific promoters likely will help in elucidating the role of this protein in controlling the symbiotic pathway.

\section{MATERIALS AND METHODS}

Plant material and growth conditions.

All the experiments were carried out with L. japonicus ecotype B-129 F9 GIFU. Seed were surface sterilized with $25 \%$ commercial bleach and $0.1 \%$ Triton, following a previously described procedure (Lombari et al. 2003). Plants were grown on solid medium with the same composition as that of $\mathrm{B} 5$ medium, except that $\left(\mathrm{NH}_{4}\right)_{2} \mathrm{SO}_{4}$ and $\mathrm{KNO}_{3}$ were omitted and replaced by $\mathrm{AS}\left(\mathrm{NH}_{4} \mathrm{OOC}\left(\mathrm{CH}_{2}\right)_{2} \mathrm{COONH}_{4}\right)$, ammonium phosphate $\left(\left(\mathrm{NH}_{4}\right)_{2} \mathrm{HPO}_{4}\right)$, or ammonium nitrate $\left(\mathrm{NH}_{4} \mathrm{NO}_{3}\right)$ at the indicated concentrations. In the case of $\mathrm{NH}_{4} \mathrm{NO}_{3}, \mathrm{AS}$, and $\mathrm{N}$ free conditions, $\mathrm{KCl}$ was added to the medium to replace the potassium source. The described media contained vitamins and the $\mathrm{pH}$ was adjusted to 5.7 with morpholineethanesulfonic acid. All plants were cultivated in growth chambers at $23^{\circ} \mathrm{C}$ with a 16-h photoperiod and light intensity of $246 \mu \mathrm{E} \mathrm{s}^{-1} \mathrm{~m}^{-2}$.

\section{In vitro nodulation.}

Growth conditions and the Mesorhizobium loti inoculation procedure for the in vitro nodulation assay have been reported elsewhere (Barbulova and Chiurazzi 2005). M. loti strain R7A was grown to mid-log phase in liquid tryptone yeast medium and used for inoculating plants at a concentration of $10^{7}$ cells per root tip.

\section{Nod factor isolation.}

Nod factors were kindly provided by Prof. M. Hayashi. They were bulk purified from M. loti strain MAFF303099 harboring the plasmid pMP2112 (Lopez-Lara et al. 1995) and represent a mixture of different Nod factors (Niwa et al. 2001).

\section{Nod factor application,}

Surface-sterilized GIFU seed were germinated on the appropriate media ( $1 \%$ agar) containing various $\mathrm{N}$ sources. Four-dayold seedlings with straight roots $(1 \mathrm{~cm})$ were selected and grown for two additional days. For spot inoculation, Nod factor solution was mixed with $1 \%$ low-melt agarose prewarmed to $55^{\circ} \mathrm{C}$. One microliter of this solution $\left(10^{-8}\right.$ to $\left.10^{-9} \mathrm{M}\right)$ was spot inoculated onto the roots at the emerging root hair zone. For RNA expression analysis, plants were germinated and grown on sterile filter paper applied to the surface of media containing appropriate $\mathrm{N}$ sources. Nod factor solution $\left(10 \mu \mathrm{l} ; 10^{-8}\right.$ to $\left.10^{-9} \mathrm{M}\right)$ was applied to the primary root tips of 6-day-old seedlings.

\section{Optical microscopy.}

Microscopic analysis was performed 5 days after spot inoculation. Root sections, approximately $0.5 \mathrm{~cm}$ in length and with the spot application area in the middle, were excised and fixed overnight with $2 \%$ paraformaldehyde and $1 \%$ glutaraldehyde.
Root sections were dehydrated stepwise, infiltrated, and embedded in Historesin (Leica Instruments, Heidelberg, Germany). Serial cross and longitudinal sections (0.5 $\mathrm{mm}$ in thickness) were stained with $1 \%$ basic toluidine blue for light microscopy.

\section{Root hair deformation assay.}

Surface-sterilized GIFU seed were germinated on appropriate media containing different $\mathrm{N}$ sources. Four-day-old seedlings with straight roots $(1 \mathrm{~cm}$ long) were selected and transplanted to Fahraeus slides, containing the liquid medium described by Heidstra and associates (1994). LCOs were added at $10^{-8}$ to $10^{-10} \mathrm{M}$. Before Nod factor application, all samples were examined by microscopy and only seedlings with straight root hairs were selected for the assay.

\section{Quantitative real-time RT-PCR.}

Total RNA was prepared from Lotus roots 24 to $48 \mathrm{~h}$ after LCO application, by following the procedure reported by Kistner and Matamoros (2005). The samples were treated with DNAse I (Ambion, Austin, TX, U.S.A.) to remove contaminating DNA,. Total RNA $(1 \mu \mathrm{g})$ was annealed to random decamers and reverse-transcribed with reverse transcriptase (Ambion) to obtain cDNA. Real-time PCR was performed with a DNA Engine Opticon 2 System (MJ Research, Watertown, MA, U.S.A.) using SYBR to monitor dsDNA synthesis. The ubiquitin gene was used as an internal standard. The concentration of primers was optimized for each PCR reaction and each amplification was carried out in triplicate. The program used was as follows: $95^{\circ} \mathrm{C}$ for $13 \mathrm{~min}$ and 39 cycles of $94^{\circ} \mathrm{C}$ for $15 \mathrm{~s}, 63^{\circ} \mathrm{C}$ for $15 \mathrm{~s}$, and $72^{\circ} \mathrm{C}$ for $15 \mathrm{~s}$. Data were analyzed using Opticon Monitor Analysis Software (version 2.01; MJ Research). The relative level of expression was calculated with the following formula: relative expression ratio of the gene of interest is $2^{-\Delta \mathrm{CT}}$ with $\Delta \mathrm{CT}=\mathrm{Ct}_{\mathrm{gene}}$ minus $\mathrm{CT}_{\mathrm{UBI}}$. The analysis of the melting curve revealed a single narrow peak for each amplification product, and fragments amplified from total cDNA were gel purified and sequenced to assure accuracy and specificity.

The specific primers for the genes analyzed were as follows (the size of the PCR products is indicated in parentheses):

NIN-F1 5' GGGCAAATGAGTTCAGGATT 3' (128 bp)

NIN-R1 5' GCCTTGGTTCGTCTCTTCTC 3'

NSP1-F1 5' TGCTTCAATCCTGCAAGTTC 3' (68 bp)

NSP1-R1 5' TGTCAAGGATGTGGAGGGTA 3'

TINod (NSP2)-F1 5' GACGACTTCCACCACCTCAT 3' (151

$\mathrm{bp)}$

TINod (NSP2)-R1 5' TGGTTGTTGTTGTCGTGGTT 3'

NFR5-F1 5'GATTTCAGCGATGAGTGCAA 3' (168 bp)

NFR5-R1 5'GCCTGAGGAGACACCCATTA 3'

NFRl-F1 5'CAGGTCTAGCTAGTGGTGCA 3' (190 bp)

NFRl-R1 5'GCCCACTGGATCCAGAAGTT 3'

CASTOR F-1 5' CTGCTGCTCCGAAATACACA 3' (210 bp)

CASTOR R-1 5' TCTCGCCCTACAGAGGAAAA 3'

POLLUX F-1 5' CCACCACCAGGAAAAGAAGA 3' (210 bp)

POLLUX R-1 5'GAGAGCGGTGGTTATGGTGT 3'

UBI F-1 5' TTCACCTTGTGCTCCGTCTTC 3' (78 bp)

UBI R-1 5'AACAACAGCACACACAGACAATCC 3'.

\section{Statistical analysis.}

Statistical analysis was performed with an analysis of variance program provided online by Vassar College.

\section{ACKNOWLEDGMENTS}

This work was supported by a grant from the EEC (INTEGRAL: MRTNCT-2003-505227), MIUR (Fondo per gli Investimenti della Ricerca di Base RBNE01KZE7_001), and MIPAF (Progetto Speciale, Risorse genetiche di organismi utili per il miglioramento di specie di interesse agrario e per 
un'agricoltura sostenibile). S. Omrane was supported by an EEC fellowship (INTEGRAL: MRTN-CT-2003-505227). We wish to thank J. Stougaard for providing seed of the L. japonicus harl-3 mutant (Krusell et al. 2002), M Hayashi for purified Nod factor, and A. Downie for providing the sequences of the LjNSP1 primers before publication. We thank M. Cermola and the IGB-E.M service for preparation of semithin sections and R. Vito, N Bellopede, and M. Terracciano for technical assistance. The authors particularly wish to thank B. Giordano and the gardeners of the Royal Botanical Garden of Naples for their excellent work with plant care.

\section{LITERATURE CITED}

Ané, J. M., Kiss, G. B., Riely, B. K., Penmetsa, R. V., Oldroyd, D., Ayax, C., Levy, J., Debellè, F., Baek, J. M., Kalo, P., Rosenberg, C., Roe, B. A., Long, S. R., Dénarié, J., and Cook, D. R. 2004. Medicago truncatula DMI1 is required for bacterial and fungal symbioses in legumes. Science 303:1364-1367.

Barbulova, A., and Chiurazzi, M. 2005. Procedure for Lotus japonicus in vitro nodulation studies. Pages 83-86 in: Lotus japonicus Handbook. A. J. Marquez, ed. Springer Verlag, Dordrecht, The Netherlands.

Bisseling, T., van den Bos, R. C., and van Kammen, A. 1978. The effect of ammonium nitrate on the synthesis of nitrogenase and the concentration of leghemoglobin in pea root nodules induced by Rhizobium leguminosarum. Biochim. Biophys. Acta 539:1-11.

Borisov, A. Y., Madsen, L. H., Tsyganov, V. E., Umehara, Y., Voroshilova, V. A., Batagov, A. O., Sandal, N., Mortensen, A., Schauser, L., Ellis, N. Tikhonovich, I. A., and Stougaard, J. 2003. The sym35 gene required for root nodule development in pea is an ortholog of nin from Lotus japonicus. Plant Physiol. 131:1009-1017.

Caetano-Anollés, G., and Gresshoff, P. M. 1991. Plant genetic control of nodulation. Annu. Rev. Microbiol. 45:345-382.

Càrdenas, L., Feijò, J. A., Kunkel, J. G., Sànchez, F., Holdaway-Clarke, T. Hepler, P. K., and Quinto, C. 1999. Rhizobium Nod factors induce increases in intracellular free calcium and extracellular calcium influxes in bean root hairs. Plant J. 19:347-352.

Carroll, B. J., and Mathews, A. 1990. Nitrate inhibition of nodulation in legumes. Pages 159-180 in: Molecular Biology of Symbiotic Nitrogen Fixation ed. P. M. Gresshoff, ed. CRC Press, Boca Raton, FL, U.S.A.

Cho, M., and Harper, J. E. 1991. Effect of localized nitrate application on isoflavonoid concentration and nodulation in split-root systems of wildtype and nodulation-mutant soybeans plants. Plant Physiol. 95:1106-1112.

Endre, G., Kereszt, A., Kevei, Z., Mihacea, S., Kalo, P., and Kiss, G. B. 2002. A receptor kinase gene regulating symbiotic nodule development. Nature 417:962-966.

Ehrhardt, D. W., Atkinson, E. M., and Long, S. R. 1992. Depolarization of alfalfa root hair membrane potential by Rhizobium meliloti Nod factors. Science 256:998-1000.

Ehrhardt, D. W., Wais, R., and Long, S. R. 1996. Calcium spiking in plant root hairs responding to Rhizobium nodulation signals. Cell 85:673-681.

Felle, H. H., Kondorosi, E., Kondorosi, A., and Schultze, M. 1996. Rapid alkalinization in alfalfa root hairs in response to rhizobial lipochitooligosaccharide signals. Plant J. 10:295-301.

Felle, H. H., Kondorosi, E., Kondorosi, A., and Schultze, M. 1999. Elevation of the cytosolic free $(\mathrm{Ca} 2+)$ is indispensable for the transduction of the Nod factor signal in alfalfa. Plant Physiol. 121:273-280.

Gleason, C., Chaudhuri, S., Yang, T., Munoz, A., Poovaiah, B. W., and Oldroyd, G. E. D. 2006. Nodulation independent of rhizobia induced by a calcium-activated kinase lacking autoinhibition. Nature 441:1149-1152.

Gonzalez-Rizzo, S., Crespi, M., and Frugier, F. 2006. The Medicago truncatula CREI cytokinin receptor regulates lateral root development and early symbiotic interaction with Sinorhizobium meliloti. Plant Cell $18: 2680-2693$.

Heckmann, A. B., Lombardo, F., Miwa, H., Perry, J. A., Bunnewell, S., Parniske, M., Wang, T. L., and Downie, A. 2006. Lotus japonicus nodulation requires two GRAS domain regulators, one of which is functionally conserved in a non-legume. Plant Physiol. 142:1739-1750.

Heidstra, R., Geurts, R., Franssen, H., Spaink, H. P., van Kammen, A., and Bisseling, T. 1994. Root hair deformation activity of nodulation factors and their fate on Vicia sativa. Plant Physiol. 105:787-797.

Heidstra, R., Nilsen, G., Martinez-Abarca, F., van Kammen, A., and Bisseling, T. 1997. Nod factor-induced expression of leghemoglobin to study the mechanism of $\mathrm{NH}_{4} \mathrm{NO}_{3}$ inhibition on root hair deformation. Mol. Plant-Microbe Interact. 10:215-220.

Hussain, A. K. M., Jiang, Q., Broughton, W. J., and Gresshoff, P. M. 1999. Lotus japonicus nodulates and fixes nitrogen with the broad host range Rhizobium sp. NGR234. Plant Cell Physiol. 40:894-899.

Imaizumi-Anraku, H., Takeda, N., Charpentier, M., Perry, J., Miwa, H., Umehara, Y., Kouchi, H., Murakami, Y., Mulder, L., Vickers, K., Pike, J., Downie, J. A., Wang, T., Sato, S., Asamizu, E., Tabata, S., Yoshikawa,
M., Muroooka, Y., Wu, G. J., Kawaguchi, M., Kawasaki, S., Parniske, M., and Hayashi, M. 2005. Plastid proteins crucial for symbiotic fungal and bacterial entry into plant roots. Nature 433:527-531.

Jacobs, M., and Rubery, P. H. 1988. Naturally occurring auxin transport regulators. Science 241:346-349.

Kalò, P., Gleason, C., Edwards, A., Marsh, J., Mitra, R. M., Hirsch, S., Jakab, J., Sims, S., Long, S. R., Rogers, J., Kiss, G. B., Downie, J. A., and Oldroyd, D. 2005. Nodulation signaling in legumes requires NSP2, a member of the GRAS family of transcriptional regulators. Science 308:1786-1789.

Kanamori, N., Madsen, L. H., Radutoiu, S., Frantescu, M., Quistgaard, E. M. H., Miwa, H., Downie, A. J., James, E. K., Felle, H. H., Haaning, L. L., Jensen, T. H., Sato, S., Nakamura, Y., Tabata, S., Sandal, N., and Stougaard, J. 2006. A nucleoporin is required for induction of $\mathrm{Ca} 2+$ spiking in legume nodule development and essential for rhizobial and fungal symbiosis. PNAS 103:359-364.

Kistner, C., and Matamoros, M. 2005. RNA isolation using phase extraction and $\mathrm{LiCl}$ precipitation. Pages 123-124 in: Lotus japonicus Handbook. A. J. Marquez, ed. Springer Verlag, Dordrecht, The Netherlands.

Krusell, L., Madsen, L. H., Sato, S., Aubert, G., Genua, A., Szczyglowski, K., Duc, G., Kaneko, T., Tabata, S., de Bruijn, F., Pajuelo, E., Sandal, N., and Stougaard, J. 2002. Shoot control of root development and nodulation is mediated by a receptor-like kinase. Nature 420:422-426.

Levy, J., Bres, C., Geurts, R., Chalhoub, B., Kulikova, O., Duc, G., Journet, E. P., Anè, J. M., Lauber, E., Bisseling, T., Dènariè, J., Rosenberg, C., and Debellé, F. 2004. A putative $\mathrm{Ca} 2+$ and calmodulin-dependent protein kinase required for bacterial and fungal symbioses. Science 303:13611364

Limpens, E., Franken, C., Smit, P., Willemse, J., Bisseling, T., and Geurts, R. 2003. LysM domain receptor kinases regulating rhizobial Nod factorinduced infection. Science 302:630-633.

Little, D. Y., Rao, H., Oliva, S., Daniel-Vedele, F., Krapp, A., and Malamy, J. E. 2005. The putative high-affinity nitrate transporter NTR2.1 represses lateral root initiation in response to nutritional cues. Proc. Natl Acad. Sci. U.S.A. 102:13693-13698

Lombari, P., Ercolano, E., El Alaoui, H., and Chiurazzi, M. 2003. A new transformation-regeneration procedure in the model legume Lotus japonicus. Root explants as a source of large numbers of cells susceptible to Agrobacterium mediated transformation. Plant Cell Rep. 21:771-777.

Lopez-Lara, I. M., van den Berg, J. D., Oates, J. E., Glushka, J., Lugtenberg, B. J., and Spaink, H. P. 1995. Structural identification of the lipo-chitin oligosaccharide nodulation signals of Rhizobium loti. Mol. Microbiol. 15:627-638.

Madsen, E. B., Madsen, L. H., Radutoiu, S., Olbryt, M., Rakwalska, M., Szczyglowski, K., Sato, S., Kaneko., T., Tabata, S., Sandal, N., and Stougaard, J. 2003. A receptor kinase gene of the LysM type is involved in legume perception of rhizobial signals. Nature 425:637-640.

Malik, N. S., Calvert, H. E., and Bauer, W. D. 1987. Nitrate induced regulation of nodule formation in Soybean. Plant Physiol. 84:266-271.

Mitra, R. M., Shaw, S. L., and Long, S. R. 2004. Six nonnodulating plant mutants defective for Nod factor-induced transcriptional changes associated with the legume-rhizobia symbiosis. Proc. Natl. Acad. Sci. U.S.A. 101:10217-10222.

Munns, D. N. 1968. Nodulation of Medicago sativa in solution culture. III. Effects of nitrate on root hairs and infection. Plant Soil 29:33-47.

Murakami, Y., Miwa, H., Imaizumi-Anraku, H., Kouchi, H., Downie, J. A., Kawaguchi, M., and Kawasaki, S. 2007. Positional cloning identifies Lotus japonicus NSP2, a putative transcription factor of the GRAS family, required for NIN and ENOD40 gene expression in nodule initiation. DNA Res. 31:255-265.

Murray, D. J., Karas, B. J., Sato, S., Tabata, S., Amyot, L., and Sczyglowski, K. 2007. A cytokinin perception mutant colonized by Rhizobium in the absence of nodule organogenesis. Science 315:101-104.

Nishimura, R., Hayashi, M., Wu, G. J., Kouchi, H., Imaizumi, H., Murakami, Y., Kawasaki, S., Akao, S., Ohmori, M., Nagasawa, M., Harada, K., and Kawaguchi, M. 2002. HAR1 mediates systemic regulation of symbiotic organ development. Nature 420:426-429.

Niwa, S., Kawaguchi, M., Imaizumi, H., Chechetka, S. A., Ishizaka, M., Ikuta, A., and Kouchi, H. 2001. Responses of a model legume Lotus japonicus to lipooligosaccharide nodulation factors purified from Mesorhizobium loti JRL501. Mol. Plant-Microbe Interact. 14:848-856.

Patriarca, E. J., Taté, R., and Iaccarino, M. 2002. Key role of bacterial $\left.\mathrm{NH}_{4}\right)\left({ }^{+}\right)$metabolism in Rhizobium-plant symbiosis. Microbiol. Mol Rev. 66:203-222,

Penmetsa, R. V., and Cook, D. R. 1997. A legume ethylene-insensitive mutant hyperinfected by its rhizobial symbiont. Science 275:527-530.

Radutoiu, S., Madsen, L. H., Madsen, E. B., Felle, H. H., Umehara, Y., Gronlund, M., Sato, S, Nakamura. Y, Tabata. S, Sandal. N., and Stougaard, J. 2003. Plant recognition of symbiotic bacteria requires two LysM receptor-like kinases. Nature 425:585-592. 
Remans, T., Nacry, P., Pervent, M., Girin, T., Tillard, P., Lepetit, M., and Gojon, A. 2006. A central role for the nitrate transporter NRT2.1 in the integrated morphological and physiological responses of the root system to nitrogen limitation in Arabidopsis. Plant Physiol. 140:909-921.

Schauser, L., Roussis, A., Stiller, J., and Stougaard, J. 1999. A plant regulator controlling development of symbiotic root nodules. Nature 402:191-195.

Schmidt, P. E., Broughton, W. J., and Werner, D. 1994. Nod factors of Bradyrhizobium japonicum and Rhizobium sp. NGR234 induce flavonoid accumulation in soybean root exudates. Mol. Plant-Microbe Interact. 7:384-390.

Smit, P., Raedts, J., Portyanko, V., Debellé, F., Gough, C., Bisseling, T., and Geurts, R. 2005. NSP1 of the GRAS protein family is essential for rhizobial Nod factor-induced transcription. Science 308:1789-1791.

Stracke, S., Kistner, C., Yoshida, S., Mulder, L., Sato, S., Kaneko, T., Tabata, S., Sandal, N., Stougaard, J., Szczyglowski, K., and Parniske, M. 2002. A plant receptor-like kinase required for both bacterial and fungal symbiosis. Nature 417:959-966.

Timmers, A. C., Auriac, M. C., and Truchet, G. 1999. Refined analysis of early symbiotic steps of the Rhizobium-Medicago interaction in relationship with microtubular cytoskeleton rearrangements. Development 12:3617-3628.

Tirichine, L., Imaizumi-Anraku, H., Yoshida, S., Murakami, Y., Madsen, L. H., Miwa, H., Nakagawa, T., Sandal, N., Albrektsen, A. S., Kawaguchi, M., Downie, A., Sato, S., Tabata, S., Kouchi, H., Parniske, M., Kawasaki, S., and Stougaard, J. 2006a. Deregulation of a $\mathrm{Ca} 2+/$ calmodulin-dependent kinase leads to spontaneous nodule development. Nature 441:1153-1156.

Tirichine, L., James, E. K., Sandal, N., and Stougaard, J. 2006b. Spontane- ous root-nodule formation in the model legume Lotus japonicus: a novel class of mutants nodulates in the absence of rhizobia. Mol. PlantMicrobe Interact. 19:373-382.

Tirichine, L., Sandal, N., Madsen, L. H., Radutoiu, S., Albrektsen, A. S., Sato, S., Asamizu, E., Tabata, S., and Stougaard, J. 2007. A gain-offunction mutation in a cytokinin receptor triggers spontaneous root nodule organogenesis. Science 315:104-107.

Tolley-Henry, L., and Raper, D. J. 1986. Utilization of ammonium as nitrogen source. Plant Physiol. 82:54-60.

Truchet, G., Barker, D. G., Camut, S., De Billy, F., Vasse, J., and Huguet, T. 1989. Alfalfa nodulation in the absence of Rhizobium. Mol. Gen. Genet. 219:65-68.

van Spronsen, P. C., Gronlund, M., Pacios Bras, C., Spaink, H. P., and Kijne, J. W. 2001. Cell biological changes of outer cortical root cells in early determinate nodulation. Mol. Plant-Microbe Interact. 14:839-847.

Walker, S. A., Viprey, V., and Downie, J. A. 2000. Dissection of nodulation signaling using pea mutants defective for calcium spiking induced by Nod factors and chitin oligomers. Proc. Natl. Acad. Sci. U.S.A. 97:13413-13418.

Wopereis, J., Pajuelo, E., Dazzo, F. B., Jiang, Q., Gresshoff, P. M., De Bruijn, F. J., Stougaard, J., and Szczyglowski, K. 2000. Short root mutant of Lotus japonicus with a dramatically altered symbiotic phenotype. Plant J. 23:97-114.

\section{AUTHOR-RECOMMENDED INTERNET RESOURCE}

Vassar College VassarStats webpage:

faculty.vassar.edu/lowry/VassarStats.html 